\title{
Maciej Malarski*
}

(iD https://orcid.org/0000-0002-9731-7092

\section{System wynagradzania - wybrane aspekty pomiaru efektywności}

Streszczenie: System wynagradzania jest jednym z najważniejszych składowych motywacji w przedsiębiorstwach. Prawidłowo zbudowany przyczynia się do właściwej aktywności pracowników, ukierunkowanej na realizację celów przedsiębiorstwa, wykazujących właściwe zachowania i postawy. Niniejsze opracowanie jest próbą określenia tego w jaki sposób można mierzyć efektywność systemu wynagradzania biorąc pod uwagę różne wymiary pomiaru.

Słowa kluczowe: system wynagradzania, pomiar, efektywność.

\section{Wstęp}

W obecnych, złożonych i szybko zmieniających się warunkach społeczno-ekonomicznych panujących w otoczeniu biznesowym coraz większe znaczenie w zarządzaniu przedsiębiorstwami odgrywają dobrze zaprojektowane i funkcjonujące systemy wynagradzania. Winny one być dopasowywane do aktualnej sytuacji przedsiębiorstwa oraz warunków panujących w otoczeniu, w tym w szczególności na rynku pracy. Systemy wynagradzania budowane $z$ wielu elementów powinny być powiązane i współbieżne z innymi systemami zarządzania zasobami ludzkimi. Ich stopień skomplikowania i złożoność odzwierciedlają konieczność motywowania różnych grup pracowników o odmiennych potrzebach i aspiracjach.

Przygotowany i wdrożony system wynagradzania może i powinien podlegać ciągłej ewaluacji i dostosowywaniu do bieżących warunków wewnętrznych i zewnętrznych. Celem niniejszego rozdziału jest omówienie sposobów pomiaru efektywności funkcjonowania systemu wynagradzania. Autor posługuje się przeglądem koncepcji oceny efektywności oraz przedstawia własne podejście do tego tematu. Ze względu na fakt, że systemy wynagradzania są złożonymi i skomplikowanymi konstrukcjami Autor zajmuje się jedynie wybranymi sposobami oceny efektywności omawiając najważniejsze ich charakterystyki.

* Uniwersytet Łódzki, maciej.malarski@uni.lodz.pl 


\section{System wynagradzania - podstawowe założenia}

System wynagradzania jest jednym z fundamentów systemu motywacyjnego w przedsiębiorstwie. Sposób zaprojektowania, zbudowania i wprowadzania, a potem monitorowania jego efektywności jest warunkiem właściwego oddziaływania na zachowania pracowników, ich produktywność, aktywność zawodową, rozwój, a przez to na realizowanie założonych celów przedsiębiorstwa. Generalnie system wynagradzania pełni w organizacji cztery podstawowe funkcje [Kawka, 2010: 188]:

- Motywacyjną - polegającą na pobudzaniu pracowników do efektywnego wykonywania zadań, ukierunkowywania rozwoju ludzi tak, aby w przyszłości spełniali nowe wymagania przedsiębiorstwa. Właściwe operowanie składnikami wynagrodzenia powinno sprzyjać realizacji wszystkich funkcji zarządzania personelem, których ogólnym zamierzeniem jest takie kształtowanie zachowań i postaw pracowników, aby wspierali oni realizację celów rozwojowych organizacji. Funkcja ta przejawia się także w procesach pozyskiwania pracowników z rynku pracy, oddziałując na skłonność potencjalnych pracowników do aplikowania do pracy w danym przedsiębiorstwie [por. Pocztowski, 2007: 330].

- Dochodową - związaną z zapewnieniem bezpieczeństwa materialnego pracownika i jego rodziny, a tym samym realizację określonych potrzeb związanych z życiem prywatnym.

- Społeczną - poprzez kształtowanie sprawiedliwego i akceptowanego społecznie systemu wynagradzania, uzyskanie pozytywnego klimatu pracy, wpływanie na relacje interpersonalne, promowanie wartości np. pracy zespołowej, podnoszenie poziomu zaufania między pracownikami.

- Kosztową - wynagrodzenia stanowią jedne ze składników kosztów, w szczególności kosztów pracy. Każdy pracodawca dąży do takiego wyznaczania kosztów wynagrodzeń, aby osiągnąc cównowagę między celami biznesowymi, w tym utrzymywaniem konkurencyjności przedsiębiorstwa a wypełnianiem wcześniej omówionych funkcji (motywacyjnej, dochodowej i społecznej).

Biorąc pod uwagę realizację celów biznesowych przedsiębiorstwa można postawić tezę, że realizowanie funkcji motywacyjnej jest kluczowe, bowiem pracownicy, jako podstawowy zasób organizacyjny, odpowiadają za osiągnięcie właściwych efektów, a więc pobudzanie pracowników do pełnego zaangażowania i nawet poświęcania się organizacji jest warunkiem sine qua non. Drugą podstawową, a w zasadzie współbieżną z funkcją motywacyjną, jest funkcja kosztowa, która odnosi się do tego, 
jak wysokie wydatki pieniężne należy ponieść aby osiągnąć satysfakcjonujący poziom motywacji u pracowników.

Najważniejszą, utylitarną cechą systemów wynagradzania jest silne powiązanie efektów pracy i wysiłków ponoszonych przez pracowników z wysokością otrzymywanych przez nich nagród, w tym przede wszystkim nagród materialnych. Barbara Sajkiewicz twierdzi, że „prowadzi to ograniczania rozpowszechnionego do niedawna wynagradzania za kompetencje i potencjał pracowników oraz jest wyrazem dążenia do jak najbardziej ekonomicznych rozwiązań" [Sajkiewicz, 2010: 70].

System wynagradzania, który ma spełnić swoje funkcje musi być odpowiednio zaprojektowany. Franciszek Grzesiok podkreśla duży stopień skomplikowania oraz kompleksowość systemu, który obejmuje „określenie stosowanych składników wynagrodzenia, miejsce i warunki ich przyznania, zasady ustalania i aktualizowania wysokości wynagrodzeń, formy płac stosowane w przedsiębiorstwie, obowiązujące zasady kształtowania funduszu płac, warunki i kryteria ocen, awansów, podział kompetencji w zakresie płac, jak również $\mathrm{w}$ sferze technik i procedur związanych z naliczaniem i kontrolą wynagradzania" [Grzesiok, 2011: 68].

Stanisława Borkowska bardzo wyraźnie określa miejsce systemu wynagradzania $\mathrm{w}$ budowaniu mechanizmów zarządczych podkreślając znaczenie tego systemu w funkcjonowaniu przedsiębiorstwa w następujących kwestiach:

- polityki kształtowania wynagrodzeń jako narzędzia zarządzania strategicznego,

- silnego sprzężenia zwrotnego kultury organizacji i systemów wynagradzania,

- prokonkurencyjnej orientacji wynagrodzenia,

- elastyczności systemów wynagrodzeń w kształtowaniu postaw pracowników,

- powiązania wynagrodzenia z kompetencjami,

- traktowania wynagrodzenia jako elementu kompleksowych, elastycznych i spójnych systemów motywowania zwiększającej się nierówności wynagrodzeń,

- klarowności i jednoznaczności systemu wynagrodzeń jako czynnika wzmacniającego konkurencyjność [Borkowska, 2004: 50]. 


\section{Miary efektywności}

Efektywność to jedna z tych kategorii, które wykorzystuje się do opisu stopnia sprawności funkcjonowania ludzi, systemów, całych organizacji. Przedsiębiorstwo uważane jest za efektywne, kiedy wykorzystuje w pełni posiadane zasoby w sposób zamierzony i najbardziej odpowiednio dostosowany do przyjętych celów. Efektywność oznacza też osiąganie najlepszych efektów działań przy najmniejszym w danych okolicznościach wydatku energii. Obejmuje ona zjawiska zarówno wewnątrz, a także na zewnątrz organizacji.

Efektywność jest jednym z pojęć, które są tematem rozważań przedstawicieli prakseologii. Prakseologia klasyczna „rozróżnia dwie grupy wartości - nazywanych utylitarnymi - efektywność (skuteczność) i ekonomiczność (gospodarczość) opatrywanych łącznie nazwą sprawność. Podstawową postacią sprawności jest skuteczność (efektywność). Dotyczy ona osiągania w działaniu głównego, pozytywnie ocenianego, skutku (efektu), to jest stanu zamierzonego jako cel działania. Działanie jest tym bardziej skuteczne, powiada prakseologia, w im większym stopniu jego cel został zrealizowany" [Gasparski, 1999: 34]. Można zatem stwierdzić, że skuteczność odnosi się do osiągania jak najlepszych efektów w stosunku do wyznaczonych przez podmiot celów. Ekonomiczność jest zaś ,aspektem odwołującym się do możliwie jak najlepszego wykorzystania dostępnych środków, bez zbędnych, dodatkowych czynów. Wiążą się z tym kwestie wydajności i oszczędności" [Ibidem: 34]. Działanie ekonomiczne jest zatem prowadzone w sposób możliwie najbardziej wydajny i oszczędny, czyli tak aby przy pomocy jak najmniejszego wkładu sił osiągnąć jak najlepsze rezultaty.

Stanisław Nowosielski twierdzi, że efektywność jest utożsamiana z ekonomicznością w jej węższym kontekście, natomiast w szerszym z ekonomicznością, skutecznością oraz korzystnością [Nowosielski, 2008: 124]. Korzystność z kolei to miernik, który wskazuje, czy podjęte działanie było wystarczające. Działanie korzystne to takie, przy którym wynik użyteczny będzie większy od poniesionych kosztów działania [Odlanicka-Poczobutt, 2014: 67].

Efektywność jest miarą skuteczności zarządzania tzn. „,miarą uwzględniającą sprawność i gospodarowanie, skoncentrowaną zarówno na aspekcie wewnętrznym - dotyczącym zagadnień klasycznej rozumianej produktywności, jak i zewnętrznym - obejmującym uwagi konsumentów w zakresie postrzeganej przez nich wartości" [Skrzypek, 2002: 191]. Podobnie określa to pojęcie Jadwiga Adamczyk, który podkreśla, że jest to „zdolność przedsiębiorstwa do bieżącego i strategicznego przystosowania się do 
zmian w otoczeniu oraz produktywnego wykorzystania posiadanych zasobów dla realizacji zaplanowanych celów" [Adamczyk, 1995: 33].

Ważne jest to, żeby efektywne działanie zgadzało się z akceptowaną społecznie hierarchią wartości. Dzieje się tak, gdy działanie, jak też cel tego działania, nie są związane z odrzuceniem wyższych wartości do uzyskania niższych. Działalność efektywna powinna więc być społecznie użyteczna, ta z kolei powiązana jest z efektywnością ekonomiczną. Krystyna Lisiecka podaje, iż „obok wartości ekonomiczno-finansowych kategoria efektywności wyraża również wartości społeczne, duchowe, moralne i ekologiczne. Ta druga grupa wyznacza efektywność organizacyjną zespołu działań. W kategorii efektywności zawarte są zarówno wartości ekonomiczne, jak i organizacyjne, stworzone przez przedsiębiorstwo" [Lisiecka, 2001: 4].

Efektywność może odnosić się do różnych płaszczyzn funkcjonowania organizacji w zależności od tego co jest zamierzonym celem pomiaru. Skrzypek, wyodrębnia cztery kategorie pomiaru efektywności:

- finansową - odnoszącą się wprost do osiąganych wyników ekonomicznych organizacji,

- operacyjną - wyrażoną odpowiednim poziomem produktywności procesów produkcyjnych,

- rynkową - związaną ze stopniem zaspokojenia potrzeb klientów,

- dynamiczną - dotyczącą pozyskiwania nowych idei, pomysłów i umiejętności [Skrzypek, 2002: 192].

Inny podział wymiarów efektywności proponuje Marcin Bielski, który odwołuje się do systemowego spojrzenia na funkcjonowanie organizacji. Marcin Bielski wskazuje na następujące wymiary:

- rzeczowy - pokazujący osiąganie celów zewnętrznych i zaspokojenie potrzeb społecznych,

- ekonomiczny - odzwierciedlający relację pomiędzy efektywnością i nakładami,

- systemowy - wyrażony poprzez zdolność organizacji do funkcjonowania w danym otoczeniu,

- polityczny - ujmujący relacje organizacji z otoczeniem,

- kulturowy - wskazujący na zdolności organizacji do utrwalania przyjętych wartości,

- behawioralny - odnoszący się do opinii samych pracowników i wyrażający ich interesy [Bielski, 1992: 114-118].

Jaki prezentuje najbardziej rozbudowany podział rodzajów efektywności organizacyjnej:

- efektywność rzeczowa odnosząca się do realizacji misji organizacji,

- efektywność ekonomiczna związana z maksymalizacją relacji efekty -nakłady, 
- efektywność techniczno-produkcyjna określona stopniem optymalizacji doboru i wykorzystania zasobów gospodarczych,

- efektywność środowiskowa osiągana poprzez rozwój paradygmatów nauki o zarządzaniu środowiskiem,

- efektywność oparta na jakości, wyrażająca się osiąganiem założonego poziomu jakości w zarządzaniu,

- efektywność społeczna związana z koncepcją społecznej odpowiedzialności przedsiębiorstwa,

- efektywność etyczno-kulturowa wynikająca z tworzenia, utrwalania i promowania norm etycznych i kulturowych,

- efektywność behawioralna odnosząca się do realizacji interesów osób zatrudnionych w danej organizacji [Jaki, 2012: 128].

\section{Efektywność systemu wynagradzania}

Biorąc pod uwagę kompleksowość systemu wynagradzania oraz wielorakie funkcje, które powinny być pełnione przez ten system należy poszukiwać złożonego konglomeratu miar efektywności. Szukając charakterystyk związanych z określaniem poziomu efektywności systemu wynagradzania można kierować się następującymi charakterystykami tego systemu [por. Stabryła (red.), 2010; Carlsson, 2008; Borkowska, 2004, Juchnowicz, 2003: 103-130]:

- określenie ekonomicznego powiązania systemu z funkcjonowaniem przedsiębiorstwa,

- realizacja polityk personalnych, $w$ tym: intensyfikacji zaangażowania pracowników, ich wysiłku w osiąganiu wyznaczonych celów organizacji, utrzymanie wartościowych pracowników, ukierunkowanie rozwoju pracowników,

- wzmacnianie wartości organizacyjnych i przyjętych zasad zachowań pracowników oraz zapewnienie identyfikacji pracowników z podejmowanymi działaniami oraz celami przedsiębiorstwa,

- optymalne wykorzystanie potencjału pracowników w celu realizacji założeń strategicznych przedsiębiorstwa,

- zwiększenie efektywności pracowników przez uzależnienie wysokości wynagrodzenia od wyników pracy,

- zapewnianie sprawiedliwości wewnętrznej wyrażonej pozytywnymi odczuciami pracowników co do właściwego nagradzania ludzi,

- zwiększanie konkurencyjności zewnętrznej związanej z przyciąganiem wartościowych kandydatów do pracy i budowaniem lojalności wśród pracujących osób,

- wzmacnianie motywacji poszczególnych grup pracowniczych. 
W ramach wyznaczania ekonomicznej efektywności systemu wynagradzania niewątpliwie należy posługiwać się kosztami związanymi z tworzeniem funduszu wynagrodzeń w przedsiębiorstwie w odniesieniu do innych parametrów ekonomicznych. Utworzone wskaźniki mogą służyć do wyznaczania tendencji związanych z udziałem wydatków na wynagrodzenia $\mathrm{w}$ innego typu kosztach ponoszonych przez przedsiębiorstwo np. udział kosztów wynagrodzeń w całkowitych kosztach sprzedaży lub stosunek kosztów wynagrodzeń do kosztów produkcji.

Innym sposobem oceny efektywności jest odniesienie kosztów wynagrodzeń do wielkości związanych z funkcjonowaniem przedsiębiorstwa: produkcji w ujęciu wartościowym oraz przychodów ze sprzedaży, co wiąże się z określaniem produktywności zasobów ludzkich. W takich porównaniach można posługiwać się produktywnością cząstkową odnosząc osiągane wyniki wytworzenia grup produktowych do kosztów wynagrodzeń ponoszonych do ich wytworzenia. Podobnie, wskaźnikiem cząstkowym byłoby odniesienie wielkości sprzedaży grup produktowych do kosztów wynagrodzeń związanych z ich wytworzeniem lub sprzedażą. Stosowanie wskaźników cząstkowych wydaje się właściwym rozwiązaniem, tam gdzie należy określić efektywność wynagrodzeń pracowników, którzy są zaangażowani w wykonywanie zadań przypisanych do konkretnego efektu. W takiej sytuacji wymagane jest posiadanie w przedsiębiorstwie rozbudowanego systemu zbierania i analizy informacji kontrolingowej.

Do oceny efektywności systemu wynagradzania w realizacji polityk personalnych można stosować wskaźniki, które odnoszą się do stopnia wypełniania tych polityk. Organizacja The Accounting for People Task Force zaproponowała kilka podstawowych wskaźników pomiaru efektywności systemu wynagrodzeń. Wśród nich wymienia się:

- profil zatrudnionego personelu - stopień dopasowania zatrudnionego personelu do wymagań kompetencyjnych stanowisk pracy i zdolność do wypełniania przypisanych zadań wyrażony poziomem wynagrodzenia stałego,

- wskaźnik fluktuacji pracowników - liczba odchodzących pracowników w wyniku niezadowolenia z osiąganego wynagrodzenia,

- wskaźnik retencji pracowników - liczba osób pozostających w przedsiębiorstwie dłużej niż przyjęty czas (zwykle w okresach 5-, 10-, 15- i 20-letnich),

- wskaźnik absencji pracowników - utrata przez przedsiębiorstwo korzyści ekonomicznych związanych z nieobecnością pracowników,

- zaangażowanie pracowników - określane np. jako liczba osób biorących udział w programach promujących działania zwiększające produktywność pracy typu kaizen lub osiąganych korzyści ekonomicznych poprzez te programy. 
Ocena poziomu wzmacniania wartości organizacyjnych i przyjętych zasad zachowań pracowników stanowi kolejny sposób pomiaru efektywności systemu. W behawioralnym sensie można ją oszacować, kiedy wartości jednostki oraz organizacji są zintegrowane, w takim przypadku efektywność działań jest potencjalnie bardzo wysoka, ponieważ jednostka stara się maksymalnie wykorzystać własne umiejętności, aby cele organizacji zostały osiągnięte [por. Juchnowicz, 2003: 111]. Pomiar wzmacniania wartości i zasad może być dokonywany poprzez porównanie oceny zachowań pracowników i ich zgodności z regułami oraz standardami organizacyjnymi ze środkami wydatkowanymi na te składniki wynagradzania, które są powiązane z tą oceną.

Korelacja efektywności systemu wynagradzania z efektywnością pracowników wydaje się oczywistym powiązaniem. W związku z tym kolejną miarą jest właśnie ocena osiąganych efektów i zakładanych wyników pracy, norm jakości, zachowania standardów pracy przez pracowników w stosunku do wypłacanych im wynagrodzeń.

Następnym kryterium oceny efektywności systemu wynagradzania jest stopień wykorzystania potencjału pracowników w realizacji założeń strategicznych przedsiębiorstwa. Ocena ta może być dokonana poprzez odniesienie funduszy wypłat za osiąganie celów lub założonych wyników przez pracowników przedsiębiorstwa do stopnia realizacji założeń strategicznych. Innym wskaźnikiem może być liczba zrealizowanych projektów rozwojowych, ich skuteczność wdrożenia i oszacowanie korzyści finansowych w porównaniu do nakładów związanych z wynagrodzeniem pracowników biorących w nich udział.

Kolejną miarą efektywności systemu wynagradzania jest ocena sprawiedliwości wewnętrznej systemu. Może być ona wyrażona jedynie poprzez opinie pracowników. Ocena ta powinna zawierać kryteria, które odnoszą się do przejrzystości i jawności zasad wynagradzania, stopnia ich akceptacji i wypełniania. Sprawiedliwość ta musi być również zauważana przez pracowników, którzy powinni dostrzegać powiązanie pomiędzy ich wkładem w realizację celów i wypełnianiem obowiązków a nagrodami finansowymi.

Pomiar konkurencyjności zewnętrznej jest związany z określeniem relacji wynagrodzeń $\mathrm{w}$ przedsiębiorstwie do wynagrodzeń osiąganych w otoczeniu. Porównanie to powinno być przeprowadzone przede wszystkim w odniesieniu do konkurentów branżowych, ale również do przedsiębiorstw, które w ramach konkretnej grupy pracowniczej są potencjalnym, konkurencyjnym miejscem pracy. Konkurencyjność zewnętrzna może również być sprawdzana serią badań związanych z pozyskiwaniem opinii od kandydatów na pracowników, pracowników pracujących w przedsiębiorstwie oraz osób które odchodzą z organizacji. 
Jeszcze inną miarą oceny efektywności systemu wynagrodzeń jest określenie poziomu motywacji i zaangażowania wyodrębnionych grup pracowników. W ramach tego kryterium powinny zostać przeanalizowane środki wydane na wynagrodzenia w podziale na grupy pracowników i porównane z ich grupowymi wynikami pracy. Często poszczególne zespoły mają specjalnie opracowane sposoby wynagradzania uzależnione od specyfiki ich pracy oraz sposobów uzyskiwania jej efektów. Badanie tego w jaki sposób komponenty wynagrodzeń wpływają na wkład pracy jest jednocześnie sprawdzaniem efektywności systemu.

Dokonanie analizy efektywności systemu wynagrodzeń wymaga gromadzenia wielu, różnorodnych informacji dotyczących rozlicznych zjawisk ekonomicznych i społecznych. Do podstawowych źródeł informacji o systemie motywacyjnym można zaliczyć:

- prowadzoną dokumentację dotyczącą pracowników, ich wynagrodzeń, finansów przedsiębiorstwa,

- regulaminy organizacyjne, pracy, wynagradzania, premiowania,

- ponoszone koszty pracy w przekrojach grup stanowisk, działów, grup pracowniczych,

- wyniki badań dotyczących oceny i opinii pracowników [Tyrańska, 2013: 35].

\section{Zakończenie}

W niniejszym rozdziale przedstawiono wybrane sposoby oszacowania efektywności systemów wynagrodzeń. Należy podkreślić, że systemy wynagrodzeń są częścią całego zestawu mechanizmów pobudzania motywacji i wpływania na zachowania ludzi. W związku z tym trudno jest oceniać funkcjonowanie systemu wynagrodzeń w oderwaniu od innych rozwiązań z zakresu zarządzania zasobami ludzkimi. Każdy z opisanych sposobów oceny wymaga szczegółowego dopracowania $\mathrm{w}$ zależności od sytuacji i wprowadzonych rozwiązań w ramach zarządzania zasobami ludzkimi. W przypadku słabego poziomu rozwoju funkcji personalnych wskazane zależności i tym samym sposoby oceny wpływu systemu wynagradzania (jego efektywności) na różne kategorie funkcjonowania przedsiębiorstwa, wydają się być bardziej jednoznaczne. Reasumując warto podkreślić, że Autor, na podstawie powyższej analizy, jest świadomy potrzeby dalszych rozważań związanych $\mathrm{z}$ doprecyzowaniem metod pomiaru efektywności systemu wynagrodzeń, a przedstawione miary stanowią podstawę do przeprowadzenia kolejnych badań. 


\section{BIBLIOGRAFIA}

Adamczyk J. (1995), Efektywność przedsiębiorstw sprywatyzowanych, Kraków.

Bielski M. (1992), Organizacja: istota, struktury, procesy, Łódź.

Borkowska S. (2004), Strategie wynagrodzeń, Oficyna Ekonomiczna, Kraków.

Carlsson P. (2008), Ksztaltowanie wynagrodzeń, BL Info Polska Sp. z o.o., Białystok.

Gasparski W. (1999), Prakseologia, Warszawa.

Grzesiok F. (2011), System wynagrodzeń a innowacyjność, „Organizacja i Zarządzanie”, nr 70, s. 65-80.

Jaki A. (2012), Mechanizmy procesu zarządzania wartościa przedsiębiorstwa, Wydawnictwo Uniwersytetu Ekonomicznego w Krakowie, Kraków.

Juchnowicz M. (2003), Konstrukcja systemu wynagrodzeń, [w:] M. Juchnowicz (red.), Narzędzia i praktyka zarzadzania zasobami ludzkimi: praca zbiorowa, POLTEXT, Kraków.

Kawka T. (2010), Wynagrodzenia pracowników, [w:] T. Listwan (red.), Zarządzanie kadrami, Wydawnictwo C.H. Beck, Warszawa.

Lisiecka K. (2001), Systemy zarzadzania jakościa i kryteria pomiaru ich efektywności, Warszawa.

Nowosielski S. (2008), Skuteczność i efektywność realizacji procesów gospodarczych, [w:] T. Dudycz, Z. Wilimowska (red.), Efektywność funkcjonowania szkót wyższych, Indygo Zahir Media, Wrocław.

Odlanicka-Poczobutt M. (2014), Prakseologia a klasyczne kryteria oceny sprawności systemów logistycznych, „Zeszyty Naukowe Politechniki Śląskiej”, nr 1909, s. 339-355.

Pocztowski A. (2007), Zarzadzanie zasobami ludzkimi, Polskie Wydawnictwo Ekonomiczne, Warszawa.

Sajkiewicz B. (2010), Wynagrodzenie w praktyce, „Zarządzanie Zasobami Ludzkimi”, Instytut Pracy i Spraw Socjalnych, nr 6, s. 67-78.

Skrzypek E. (2002), Jakość i efektywnosśc, Wydawnictwo Uniwersytetu Marii CurieSkłodowskiej, Lublin.

Stabryła A. (red.) (2010), Systemy controllingu, monitoringu i audytu, Wydawnictwo Mfiles.pl, Kraków.

Tyrańska M. (2013), Metodyczne aspekty analizy i oceny systemu motywacyjnego, „Zeszyty Naukowe Uniwersytetu Ekonomicznego w Krakowie", nr 915, s. 23-41.

\section{REMUNERATION SYSTEM - SELECTED ASPECTS OF MEASURING EFFECTIVENESS}

\section{SUMMARY}

The remuneration system is one of the most important components of motivation in enterprises. Properly built contributes to the proper activity of employees, aimed at achieving the goals of the enterprise, showing the right behaviors and attitudes. This chapter is an attempt to define how the effectiveness of the remuneration system can be measured, taking into account various measurement dimensions.

Keywords: remuneration system, measurement, efficiency. 